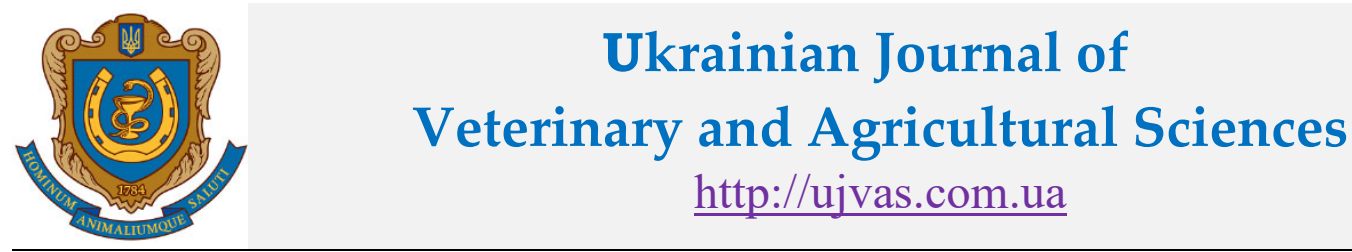

Stepan Gzhytskyi National University of Veterinary Medicine and Biotechnologies Lviv

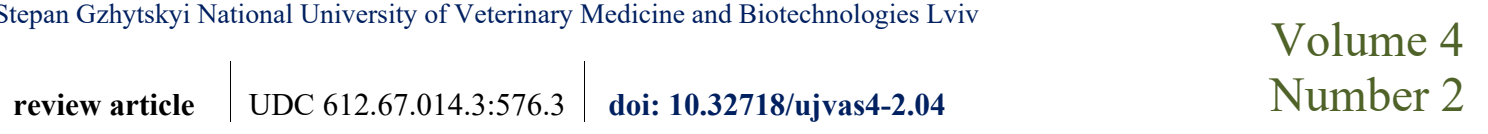

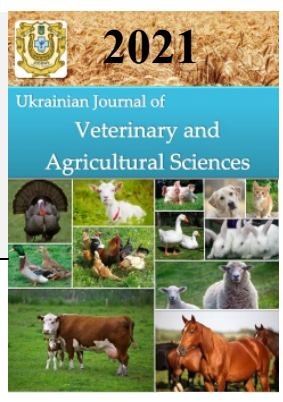

\title{
Cell death and its significance in reproductive pathology
}

\author{
M. M. Zhelavskyi ${ }^{1}$, S. P. Kernychnyi ${ }^{1}$, O. Ya. Dmytriv ${ }^{2}$ \\ ${ }^{1}$ State Agrarian and Engineering University in Podilia, Shevchenko Str., 13, Kamyanets-Podilsky, 32303, Ukraine \\ ${ }^{2}$ Stepan Gzhytskyi National University of Veterinary Medicine and Biotechnologies, Pekarska Str., 50, Lviv, 79010, Ukraine
}

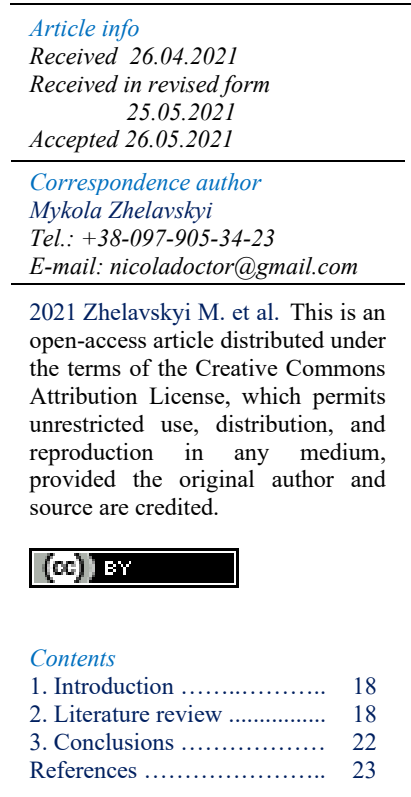

Article info

in revised for

Accepted 26.05.202

Correspondence author

Mykola Zhelavskyi

2021 Zhelavskyi M et al. This is an open-access article distributed under the terms of the Creative Commons unrestricted un reproduction in any medium, provided the original author and source are credited.

23

\begin{abstract}
Since the middle of the last century, scientists have been interested in the mechanisms of regulation of cell division, differentiation and aging of cells. The first objects of study were insects, helminths and other living organisms. From the very beginning, in the biology of cell development and regulation, scientists have attached leading importance to genetic factors. Later, more and more experience was gained on the influence of intracellular factors, metabolic changes and exogenous pathogens on the programmed cell death. Recent research on cell biology and pathology has focused on the study of apoptosis. The first described phenomenon of programmed cell death was apoptosis. Subsequent studies were aimed at the study programmed cell death. This review will provide an opportunity to consider the biological mechanisms of programmed cell death, differences and species characteristics. The author described the clinical aspects of apoptosis, necroptosis and pyroptosis and their importance in the formation of cellular homeostasis. In the present review article simple classification system, where the cell death entities are primarily categorized into programmed cell death. Multiple mechanisms and phenotypes compose programmed non-apoptotic cell death, including: autophagy, entosis, methuosis and paraptosis, mitoptosis and parthanatos, ferroptosis, pyroptosis NETosis and necroptosis. Changes of cellular regulation at development of pathologies at people and animals are considered. Cell biology includes a variety of mechanisms of programmed aging and death. Modern research is aimed at deepening the study multiple mechanisms and phenotypes compose programmed. Cells. will certainly be taken into account by the Nomenclature Committee on Cell Death. Cellular regulation is associated with a variety of physiological mechanisms of development, and is also important in processes such as inflammation, immune response, embryogenesis maintenance of tissue homeostasis. Study of factors of influence and mechanisms of regulation of aging of cells opens a curtain for development of the newest means of diagnostics of pathologies and development of pharmacological means for correction of cellular mechanisms at development of pathologies.
\end{abstract}

Key words: cellular multiple mechanisms regulation, phenotypes compose programmed cell death, reproductive pathology.

\section{Citation:}

Zhelavskyi, M. M., Kernychnyi, S. P., \& Dmytriv, O. Ya. (2021). Cell death and its significance in reproductive pathology. Ukrainian Journal of Veterinary and Agricultural Sciences, 4(2), 18-26.

\section{Introduction}

Initial cell studies were concerned with the study of structure and function. It is known that the process of division, proliferation, differentiation and survival of cells is the basis of life of all living beings (Elliott \& Ravichandran, 2016; Papayannopoulos, 2018; Cahilog et al., 2020). Over time, scientists became interested in the mechanisms of regulation of cell division, aging and cell death (Jorgensen et al., 2017; Kambara et al., 2018; Khan et al., 2021). Recently, more and more information is emerging in sources about the physiology of cells, and especially about the regulation of division, aging and death. Until recently, scientists have described the phenomena of aging and cell death without clear systematization and classification (Naderer \& Fulcher, 2018; Linkermann, 2019; Zhou et al., 2020; Zhelavskyi, 2021). Sometimes such information was incomplete, inaccurate or even contradictory. Often the same phe- nomenon described by the authors was identified or even not debated by the scientific community.

The aim of the review of our work is to make a scientific search for new reliable information on aging and cell death.

\section{Literature review}

The initial classification of cell death included three types: apoptosis, autophagy, and necrosis. Recent studies describe a number of new ways of cell death. In view of this, in 2018 the The Nomenclature Committee on Cell Death (NCCD), based on molecular principles, made a new classification of cell effort and death (Kim et al., 2019; Galluzzi et al., 2020). The principled approach in modern nomenclature is based on the division of processes related to the mechanisms of regulation of programmed and unprogrammed cell death. Programmed cell death is governed by clear intracellular signaling mechanisms. In turn, spontaneous death occurs under the influence of destructive factors. 
Given the morphological features and molecular mechanisms, cell death is divided into apoptosis and cell death with the involvement of non-apoptotic processes.

\section{Non-programmed cell death}

Necrosis. Irreversible cell injury and eventual cell death due to pathological processes are termed necrosis. It is an uncontrolled cell death that results in swelling of the cell organelles, plasma membrane rupture and eventual lysis of the cell, and spillage of intracellular contents into the surrounding tissue leading to tissue damage (Kearney \& Martin, 2017; Arifuzzaman et al., 2018; Kim et al., 2019; Robinson et al., 2019). Usually, the factors of necrosis are numerous exogenous factors: infection, toxins, exposure to various physical factors (pressure, electricity, ionizing radiation, etc.). Unlike programmed cell death known as apoptosis which generates from intrinsic signals, necrosis occurs due to overwhelming noxious stimulus from outside the cell and is almost always associated with inflammatory responses due to the release of heat shock proteins, uric acid, ATP, DNA, and nuclear proteins, which cause inflammasome activation and secretion of proinflammatory cytokine interleukin-1 beta (IL1) (Sachet et al., 2017; Tonnus \& Linkermann, 2017; Szwed et al., 2019; Xi et al., 2019). Chromatin is usually not subject to condensation and disrupts the synthesis of macromolecules. These processes in the cell occur against the background of minimal energy expenditure. Modern diagnosis of cell necrosis is based on the detece of lactate dehydrogenase activity and the use of specific cell-impermeamble DNA binding dyes (Rogers et al., 2017; Orning et al., 2017; Rijal et al., 2018).

\section{Programmed cell death}

Apoptosis. Apoptosis is a phenomenon of programmed, clearly controlled mechanisms aimed at triggering cell selfdestruction. During apoptosis, the formation of membrane blebbing on the, the positional organelles loss, condensation and fragmentation of DNA (Elliott \& Ravichandran, 2016; Kolb et al., 2017; Chen et al., 2019). To date, there are three signaling pathways for apoptosis: external - through external receptors, internal (mitochondrial) and perforin / granzyme.

The initiation of apoptosis is caused by physiological signals-inducers, which are perceived by specialized cellular receptors that trigger a cascade of sequential intracellular biochemical processes (Yablonskyi \& Zhelavskyi, 2014; Lawlor et al., 2017). These signals can be a variety of factors: biologically active substances, hormonal changes, antigenic overload, the presence in the body of specific antibodies to cell receptors, cytokines, etc. The nature of the cells' response to signals is ambiguous and depends on a number of factors that affect the functional state of cells, the stage of their activation and differentiation. The perception of signals by cells is carried out through membrane receptors (Orzalli \& Kagan, 2017; Boucher et al., 2018). Currently, there are four successive stages of apoptosis: 1) the perception of apotic stimuli by cells; 2) signal transmission to intracellular regulatory elements; 3 ) the interaction of regulatory elements of target cells and "decision making" - "live or die"; 4) destruction of vital molecules of target cells by effector elements of the apoptotic pathway (Kolb et al., 2017; Lu et al., 2018; Ning et al., 2019). The process begins with the activation by the cell of potentially lethal stimuli, which can be both pathological and physiological, which causes oligomerization of intracellular receptor domains, which in turn activate other substrates that induce apoptosis.
In the second stage, the transmission of apoptotic signals to other regulatory proteins of target cells. Among the signaling proteins of apoptosis, proteolytic enzymes caspase play an important role. It is well known that caspase- 8 plays a key role in the destruction of cellular proteins during apoptosis (Rogers et al., 2017; Rathkey et al., 2018; Snyder et al., 2019). Among the mechanisms of biological cell death, the most universal is the influence of specific Fas receptors (Fas, R2, Apo1, Cd95), which are expressed on the surface of most cells, in particular they are contained on the membrane of activated T-, B-lymphocytes, antigen-presenting cells, fibroblasts, keratinocytes cells that have been transformed during the reproduction of viruses, etc. The Fas receptor, like the tumor necrosis factor (TNF), has a homologous structure. The third stage of apoptosis covers the processes that occur mainly in mitochondria. The fourth stage of apoptosis begins with the activation of procaspatase-9, after which it acquires the ability to activate other intracellular substrates, in particular procaspase-3, initiating the caspase cascade. This destroys the genes of many vital cell proteins, including the genes of apoptosis suppressors, which eventually leads to cell death (apoptosis) (Zhelavskyi, 2011; Zargarian et al., 2017; Zhang et al., 2019). This group of proteases exists separately and functions as a mediator of the death signal. Currently, 10 caspases have been identified in different mammalian cells, which create an enzymatic cascade, similar to the enzymatic cascade of the blood coagulation system or the complement system (Yablonskyi \& Zhelavskyi, 2010; Wang et al., 2017; Tang et al., 2020). The consequence of these biochemical metamorphoses is the compaction of chromatin, which is known to be the most important component of the intranuclear component, which contains DNA and proteins (Sborgi et al., 2016; Platnich et al., 2018). In the cascade of biochemical reactions, the nucleus breaks down into fragments with the subsequent formation of chromatin cells and the destruction of the cytoplasm (Speir et al., 2016; Zhelavskyi, 2017; Kim et al., 2018).

Anoixis is a type of apoptosis in which all the mechanisms of triggering programmed cell death are triggered, which occurs under the influence of inadequate factors or when the cell-matrix mechanism does not correspond to the interaction. The state of the cytoskeleton has been reported to be related to the functional state of integrin (survival effector). Recent studies have shown that signal transduction from c-JUN NH2-terminal kinase (JNK) is necessary for effective anoixis involving BAK / BAX-dependent exposure (Elliott \& Ravichandran, 2016; Galluzzi et al., 2020). This is due to increased expression of BCL2-like 11 (BIM) and phosphorylation of BCL-2 modification factor (BMF) (Evavold et al., 2016). Modern methods for determining anoixis are determination of terminal deoxynucleotidyltransferase dUPT by labeling (TUNEL), use of annexin V, determination of caspases and lysis by poly-ADP-ribose polymerase (PARP), determination of specific inhibitors of apoptosis (including pancapase inhibitor, zVAD-fmk).

\section{Programmed cell death of non-apoptotic origin}

Autophagy is a cell death characterized by intracellular large bubbles, the formation of vesicles in the plasma membrane blebbing, enlargement and depletion of organelles in the absence of chromatin condensation. Autophagy is considered as a trigger process under cellular stress and initially performs a protective reaction (Yu et al., 2018; Levine et al., 2019; Wei et al., 2019). To date, there are three forms: mac- 
ro-autophagy, micro-autophagy and chaperone-mediated autophagy. Macro-autophagy is accompanied by the process of covering a separate area of cytoplasm with a membrane structure with the capture of organelles. As a result, a fragment is formed isolated from other cellular structures by a double layer of membrane. This indicates the formation of an autophagosome, which subsequently merges with the lysosomes and the active process of digestion of its contents (Levine \& Kroemer, 2019). It is believed that such a mechanism makes it possible to implement the process of destruction of organelles (mitochondria, ribosomes, etc.) that have "served their life" (Jorgensen et al., 2017; Chen et al., 2019; Levine \& Kroemer, 2019).

Micro-atophagy is accompanied by cytoplasmic sequestration. With the participation of acid hydrolases, cell degradation occurs. Autophagy through chaperones selectively affects proteins that contain KFERQ motif (Lys-Phe-GluArg-Gln)-containg proteins. These proteins themselves are markers that are captured by lysosomes through chaperones and are destroyed. By origin, there are mitophagia - degradation of mitochondria; xenophagia (selective autophagy of foreign pathogens); lipophagia, aggrephagia, lysophagia, etc (Ganesan et al., 2017; Levine \& Kroemer, 2019). The third type of autophagy is chaperone-metiated. This method is the directed transport of partially denatured cytoplasmic proteins across the membrane into the lysosome cavity. Modern research methods are mainly focused on the study of macroautophagy, based on the determination of autophanic activity (eg, long-lived protein metabolism and LDH sequestration) and indirect analysis using autophagy-specific antibodies by western blot-based, analysis using fluorescence microscopy and flow cytometric microscopy.

Entosis (cannibalism of cells) - is characterized by the formation of a cell that initiates the death of the host cell. The process can be lengthy and begins after internalization (Hocsak et al., 2017; Kolb et al., 2017; Linkermann, 2019; Mlynarczuk-Bialy et al., 2020). Death is accompanied by lysosomal degradation in the middle and start and nonapoptotic cell death. The process can often be accompanied by elimination from the host cell. Entositis has also been shown to be caused by detachment of the integrinextracellular matrix. Unlike phagocytosis, the uptake of entos cells is a self-controlled process by RhoA, which is linked to RhoA helixes containing protein kinases (Hayashi et al., 2020). The entosis cell and the host cell interact with each other through the interface of the cells of E-cadherin and $\alpha$-catenin. RhoA and containing protein kinases in entos cells lead to the specific accumulation and enhancement of the interaction of actin and myosin (actomyosin complex) in the cell wall and at the junctions leads to the formation of entos cells. Autophagic protein associated with protein light chain 3 (LC3) microtubules is not involved in autophagosome formation. Instead, LC3 is sent to single-membrane vacuoles in the host cell in which the absorbed cell is located by lipidation with an autophagy-related protein (ATG) 5, ATG7, and Vps34, causing lysosomal fusion with subsequent mediated lysosomal degradation (Crawford et al., 2018; Galluzzi et al., 2020). To date, the indication of enthos is carried out using fluorescent imaging and electron microscopy.

Methuosis. Methuosis is a form of cell death characterized by the formation of massive single membrane vacuoles. Methuosis occurs against the background of macropinosis with hyperactivation of Ras and impaired apoptosis. Further morphology resembles necrosis in the form of swelling of cells and loss of integrity of the plasma membrane. However, in metuosis, activated Ras stimulates micropinocytosis due to subsequent activation of small GTPase 1 of the Rac family (Yang et al., 2019; Adjemian et al., 2020). Decreased ADF 6-GTP (Arf6-GTP) ribosylation factor activity prevents macropinosis recycling. Abnormal fusion causes vacuolation of the cytoplasm. Vacuoles formed in the early stages of metuosis contain late endosomal markers (lysosomal-associated membrane protein 1 and Rab7) (Yang, 2019). Massive vacuoles will eventually lead to cell death. Metuosis with its typical morphology is often assessed by electron microscopy (Adjemian et al., 2020; Ritter et al., 2021).

Paraptosis. A hallmark of paraptosis is massive cytoplasmic vacuolation, which occurs due to the expansion of the endoplasmic reticulum or the mitochondria. It has been reported that activation of insulin-like growth factor receptor 1 and its signaling, including mitogen-activating protein kinase, can cause paraptosis (Fatokun et al., 2014; Kessel, 2019). A number of studies have shown that paraptosis is associated with the generation of reactive oxygen species and the accumulation of improperly folded proteins in the endoplasmic reticulum, as well as the of mitochondrial $\mathrm{Ca}^{2+}$ overload which increase osmotic pressure and cause expansion of the endoplasmic reticulum and mitochondrial lumens with further development (Kessel, 2019; 2020). Research methods to date are not perfect enough and are mainly aimed at determining multiple or single cytoplasmic vacuoles detected by electron microscopy.

Mitoptosis - mitochondrial death cell, the process of programmed division and fusion of mitochondria with concomitant disruption of adenosine triphosphate (Giampazolia et al., 2017; Lyamzaev et al., 2020). Mitoptosis can be associated with both apoptosis and autophagy (Gong et al., 2017). According to the initial thought, mitoptosis serves to protect cells from malfunctioning of the damaged mitochondria. At the same time, a new mechanism of the complete mitochondria elimination was found under the conditions of massive mitochondrial damage associated with oxidative stress. In this experimental model, mitochondrial cluster formation in the perinuclear region leads to the formation of "mitoptotic body" surrounded by a single-layer membrane and subsequent release of mitochondria from the cell. Later, it was found that mitoptosis plays an important role in various normal and pathological processes that are not necessarily associated with the mitochondrial damage. It was found that mitoptosis takes place during cell differentiation, self-maintenance of hematopoietic stem cells, metabolic remodelling, and elimination of the paternal mitochondria in organisms with the maternal inheritance of the mitochondrial DNA (Swerdlow \& Wilkins, 2020). Moreover, the associated with mitoptosis release of mitochondrial components into the blood may be involved in the transmission of signals between cells, but also leads to the development of inflammatory and autoimmune diseases. Mitoptosis can be attributed to the asymmetric inheritance of mitochondria in the division of yeast and some animal cells, when the defective mitochondria are transferred to one of the newly formed cells (Mijaljica et al., 2010).

As a method of mitochondrial suicide, visualization of fragmented mitochondria with mitochondrial-specific dyes (Mitotracker Green ${ }^{\circledR}$ ) by using fluorescence microscopy and 
electron microscopy, indication of specific antibodies against cytochrome C and TIMM8a / DDP.

Parthanatos. Parthanatos is mitochondrial-linket but caspase-independent cell death and is characterized by hyperactivation of poly (ADP-ribose)-polymerase (Fatokun et al., 2014). Cells die by a variety of mechanisms. Terminally differentiated cells such as neurones die in a variety of disorders, in part, via parthanatos, a process dependent on the activity of poly (ADP-ribose)-polymerase. Parthanatos does not require the mediation of caspases for its execution, but is clearly mechanistically dependent on the nuclear translocation of the mitochondrial-associated apoptosis-inducing factor. The nuclear translocation of this otherwise beneficial mitochondrial protein, occasioned by poly (ADP-ribose) produced through poly (ADP-ribose) overactivation, causes large-scale DNA fragmentation and chromatin condensation, leading to cell death. This review describes the multistep course of parthanatos and its dependence on poly (ADP-ribose) signalling and nuclear apoptosis-inducing factor translocation. The review also discusses potential targets in the parthanatos cascade as promising avenues for the development of novel, disease-modifying, therapeutic agents. The process can be further confirmed by mitochondrial depolarization, which can be detected by staining with fluorescent dyes.

Ferroptosis is usually associated with normal morphology, with an intact cell membrane without apoptotic vesicles and nuclear changes, reduction of mitochondria and destruction of their membranes (Aglietti \& Dueber, 2017; Friedmann et al., 2019). Inflammatory sensorsof infected macrophages recognize flagellin components of pathogens and initiate the formation of multi-protein complex inflammasomes, which subsequently activate caspase-1 (Li et., 2020). Ferroptosis is a new type of cell death that was discovered in recent years and is usually accompanied by a large amount of iron accumulation and lipid peroxidation during the cell death process; the occurrence of ferroptosis is iron-dependent. Ferroptosis-inducing factors can directly or indirectly affect glutathione peroxidase through different pathways, resulting in a decrease in antioxidant capacity and accumulation of lipid reactive oxygen species (ROS) in cells, ultimately leading to oxidative cell death (Johnson et al., 2018).

Induction of ferroptosis can be confirmed by using ferroptose inhibitors (ferrostatin-1 and liproxstatin-1) and by measuring lipid peroxide (quantification of malondialgide and quantification of 4-hydroxynonenal).

\section{Immuno-reactive cell death}

Pyroptosis is an inflammatory form of programmed cell death that usually occurs when intracellular pathogens are recognized in immune cells (Liu et al., 2019). Inflammasomes are innate immune mechanisms that promote inflammation by activating the protease caspase-1. Active caspase-1 induces pyroptosis, a necrotic form of regulated cell death, which facilitates the release of intracellular proinflammatory molecules, including IL-1 family cytokines. Recent studies identified mediators of inflammasomeassociated cell death and suggested that inflammasomes induce not only pyroptosis, but also apoptosis. Caspase-1 has the potential to induce pyroptosis and apoptosis in a manner that is dependent on the expression of the pyroptosis mediator gasdermin D. Caspase-1-induced apoptosis is mediated by Bid and caspase-7. Caspase- 8 is also activated following the formation of inflammasomes and may induce apoptosis (Zhelavskyi, 2004; Wang et al., 2019). Because inflammasomes contribute to the pathogenesis of inflammatory disorders and host defenses against microbial pathogens, a more detailed understanding of the mechanisms underlying inflammasome-associated cell death may contribute to the development of novel therapeutic strategies for inflammasome-related diseases (Zhang et al., 2019; Zhou et al., 2020). Pyroptosis can be assessed by quantifying released cytoplasmic LDH, visualizing the loss of membrane integrity by fluorescence microscopy, detecting interleukin (IL) $-1 \beta$, caspase activation, and gasdermin $\mathrm{D}$ cleavage by Western blotting (Rühl et al., 2018; Wang et al, 2019; Wu et al., 2021).

Cell death associated with extracellular neutrophil trap (NETosis). Neutrophils are located in the peripheral bloodstream only for 6-10 hours, and then get into the tissue where they perform their effector function. Priming phagocytic cells are capable of destroying pathogenic agents both in the immediate attack (killing) as well as by absorption and digestion (Zhelavskyi, 2010; Jorch \& Kubes, 2017). Phagocytes are also able to realize its function by activating metabolic reactivity, followed by the extracellular release of antimicrobial compounds. This phenomenon has been called in the scientific literature as a respiratory burst. In the phagocytes occurs biochemical activation of the hexose monophosphate shunt and NADPH oxidase of phagosome cell (Papayannopoulos, 2018). This metabolic reaction occurs against the backdrop of increasing (in ten times) consumption of cell glucose and Oxygen. NADPH oxidase converts $\mathrm{O}^{2}$ - superoxide anion $\left(\mathrm{O}^{2-}\right)$ and formation NETs (Zhelavskyi \& Yablonskyi, 2009; Zhelavskyi, 2017; Cahilog et al., 2020). Cell death is commonly segregated into necrosis and apoptosis; apoptosis being programmed cell death, for instance during development and physiological cellular turnover, whilst necrosis predominantly takes place in an unregulated manner. NETosis, like necrosis, is a mode of cell death that involves the loss of membrane integrity. During NETosis, decondensation of chromatin is thought to be initiated by peptidyl arginine deiminase 4 (PAD4); its subsequent release together with granule contents is vital in the innate immune response to infection and inflammation (Zhelavskyi et al., 2020). This suggests that in the bloodstream of healthy animals, the formation of NETs should not occur, as this may lead to occlusion of small flakes of DNA. Many authors have shown that the formation of NETs in the bloodstream mechanically disrupts blood circulation in the tissues and organs (Rebordão et al., 2017; Papayannopoulos, 2018). Blood inhibitory factors have been found to have a humoral nature. Autologous serum and blood plasma inhibit extracellular DNA release by neutrophils isolated from peripheral blood. Thus, in the systemic blood flow, in the absence of inflammation, the formation of NETs is suppressed (Zhelavskyi, 2011). Neutrophils of patients with chronic granulomatous disease are known to be unable to generate ROS due to a deficiency of the NADPH oxidase enzyme. In turn, the neutrophils of these patients were unable to form NETs. However, at least in part, the glucose oxidase enzyme compensated for the functional failure of NADPH oxidase to produce hydrogen peroxide (Jorch \& Kubes, 2017). However, under the influence of glucose oxidase, the formation of NETs significantly increased. In connection with all the above data, it can be concluded that, on the one hand, NETs function as an effective antimicrobial barrier, on the other hand - their excess leads to the development of inflammato- 
ry processes and to hemodynamic disorders in case of deficiency of counteracting regulatory mechanisms. Neutrophils are, above all, tissue cells involved in inflammatory and antimicrobial reactions. They also function actively in the mucous membrane. It is obvious that disorders of mucosal immunity contribute to the recurrent course and chronicity of local inflammatory processes (Zhelavskyi, 2015; Kambara et al., 2018; Zhelavskyi et al., 2020).

NETosis, a unique form of cell death, is initiated by the presence of pathogens or their components and most often occurs in immune cells, especially neutrophils (Zhelavskyi \& Shunin, 2017; Linkermann, 2019). After recognition of pathogens in neutrophils, cells undergo histone modification, chromatin decondensation, and a neutrophilic extracellular trap. NET comprising chromatin and antimicrobial components, including myeloperoxidase, neutrophil elastase, cathepsin G, lysozyme, lysozyme, and lysozyme. This process is facilitated by superoxide produced by NADPH oxidase 4 (NOX4), autophagy and dependent on peptidylarginine deziminase 4 (PAD4) citrated histones. Staining of co-localized proteins derived from neutrophils and extracellular DNA, as well as citrullinated histones is used to assess NETosis. In addition, cell-free DNA and DNA neutrophils, the resulting protein complexes can be detected using PicoGreen ${ }^{\circledR}$ and ELISA. Both morphology and cellrelated components of NETosis can be detected by flow cytometry (Zhelavskyi, 2015; Rijal et al., 2018).

\section{Other types cell death}

Necroptosis, also known as programmed necrosis, is characterized by the activation of receptor-interacting protein kinases through several signaling pathwaysb (Brault \& Oberst, 2017). Receptor-interacting protein kinases are activated by macromolecular complexes from various cell surface receptors: death receptors, Toll-like receptors and Tcell receptor. receptor-interacting protein kinases 1 and receptor-interacting protein kinases 3 function as key components of the necrosome (Caccamo et al., 2017). Receptorinteracting protein kinases 3 further activates a protein similar to the kinase domain of mixed origin by phosphorylation, which leads to oligomerization of kinase domain of mixed origin. Oligomerized kinase domain of mixed origin interacts with the cell membrane and penetrates it, which ultimately leads to cell death. Moreover, RIP3-dependent necroptosis is also triggered by a cytosolic DNA sensor, a DNA-dependent activator of interferon regulatory factors after viral infection or the presence of double-stranded viral DNA (Grootjans et al., 2017). Necroptosis shows necrotic morphology with rupture of the membrane and loss of organelles (Weinlich et al., 2017; Han et al., 2018).

Necroptosis can be assessed by loss of plasma membrane integrity using cell-impermeable DNA-binding dyes, release of cellular contents, including LDH, high-mobility protein group 1 and cyclophilin A, by Western blotting, mitochondrial fluorescence analysis. probes and morphology using electron microscopy. The use of specific necroptose inhibitors, such as necrostatin-1, and the identification of key pathway proteins are alternative strategies (Yoon et al., 2017; Huang et al., 2018).

While studies of cell death mechanisms were for many years focused almost solely on apoptosis, recent advances in this field clearly proved that necroptosis should be considered an essential component (Sarhan et al., 2019). The molecular machinery involved in necroptosis execution is complex, sophisticated and provides multiple layers of regula- tion, indicating that the concept of necrosis-like cell death being completely chaotic and uncontrollable is now outdated and should be substantially revised (Ros et al., 2017). Necroptotic signaling is tightly intertwined with plethora of regulatory pathways and contributes to such basic physiological reactions as inflammation, immune response, embryonic development, and tissue homeostasis maintenance (Liu et al., 2018).

The importance of cell death in reproductive pathology of animals

According to some authors, the formation of NETs is a mechanism of protection that acts in the tissues and on the surface of the mucous membranes, and is especially important in the mucosal anti-infective protection. Neutrophils leaving the tissues and leaving the mucous membranes can participate in the antimicrobial protection and in the regulation of the microbiota of the respective biotopes, secreting biocidal products (Zhelavskyi, 2007; 2017). In addition, the aggressive factors of neutrophil granules in the trap formed are linked by DNA strands. In the case of colonization of tissues or mucous membranes by representatives of normal microflora, trap components are not capable of causing the development of inflammatory responses (Zhelavskyi \& Shunin, 2017; Li et al., 2018; Martyshuk et al., 2020).

We found that in the pathogenesis of subclinical mastitis in cows, the apoptotic process of immune cells. Their corresponding changes, they showed wrinkling, vacuolation and fragmentation of the nucleus. The number of polymorphonuclear cells with vacuolation of the nucleus and cytoplasm and toxic granularity of the cytoplasm increased especially (Zhelavskyi, 2005; 2006; 2007). Often in micropreparations showed signs of cytolysis (plasmolysis) of immunocompetent cells of the secretion of the breast, which is differentiated by the available remnants of the nucleus, which is typical for a mature cell (Zhelavskyi, 2017). Microscopy of the drugs in different fields of view also revealed cells with intact integrity, but they clearly showed a decrease in cytometric size (ie, wrinkling). Often such changes occur together with metamorphoses of the nucleus (pyknosis, rexis, vacuolization), cytoplasm (shrinkage), when the cells lose their specific granularity (Zhelavskyi, 2019). Our studies have shown that activated neutrophilic granulocytes are able to combine with other neutrophils and form a NETs of combined protective NETs for pyometra of cats. Often neutrophil traps were located freely in the extracellular space, were without fixation. Sometimes neutrophilic granulocytes formed cooperative conglomerates with epithelial cells. Fixed microorganisms were detected in the grids at different stages of phagocytosis. Obviously, epithelial cells affect the anticrobial protection of phagocytic cells (Zhelavskyi, 2021).

\section{Conclusions}

Cell biology includes a variety of mechanisms of programmed aging and death. Modern research is aimed at deepening the study multiple mechanisms and phenotypes compose programmed.Cells. will certainly be taken into account by the Nomenclature Committee on Cell Death (NCCD). Cellular regulation is associated with a variety of physiological mechanisms of development, and is also important in processes such as inflammation, immune response, embryogenesis maintenance of tissue homeostasis. The study of influencing factors and mechanisms of regula- 
tion of cell aging opens the curtain for the development of new tools for disease diagnosis. Also the development of pharmacological agents for the correction of cellular mechanisms, including the development of reproductive pathologies.

Pespects for futher research. To date, trigger factors and mediators involved in the mechanisms of cell aging and death are being studied in detail. The field of research contains countless fascinating discoveries awaiting discovery.

\section{Conflict of interest}

The authors declare that there is no conflict of interest.

\section{References}

Adjemian, S., Oltean, T., Martens, S., Wiernicki, B., Goossens, V., Vanden Berghe, T., Cappe, B., Ladik, M., Riquet, F. B., Heyndrickx, L., Bridelance, J., Vuylsteke, M., Vandecasteele, K., \& Vandenabeele, P. (2020). Ionizing radiation results in a mixture of cellular outcomes including mitotic catastrophe, senescence, methuosis, and iron-dependent cell death. Cell death \& disease, 11(11), 1003. doi: 10.1038/s41419-020-03209-y.

Aglietti, R. A., \& Dueber, E. C. (2017). Recent Insights into the Molecular Mechanisms Underlying Pyroptosis and Gasdermin Family Functions. Trends in immunology, 38(4), 261-271. doi: 10.1016/j.it.2017.01.003.

Arifuzzaman, M., Ang, W., Choi, H. W., Nilles, M. L., St John, A. L., \& Abraham, S. N. (2018). Necroptosis of infiltrated macrophages drives Yersinia pestis dispersal within buboes. JCI insight, 3(18), e122188. doi: 10.1172/jci.insight.122188.

Boucher, D., Monteleone, M., Coll, R. C., Chen, K. W., Ross, C. M., Teo, J. L., Gomez, G. A., Holley, C. L., Bierschenk, D., Stacey, K. J., Yap, A. S., Bezbradica, J. S., \& Schroder, K. (2018). Caspase-1 self-cleavage is an intrinsic mechanism to terminate inflammasome activity. The Journal of experimental medicine, 215(3), 827-840. doi: 10.1084/jem.20172222.

Brault, M., \& Oberst, A. (2017). Controlled detonation: evolution of necroptosis in pathogen defense. Immunology and cell biology, 95(2), 131-136. doi: 10.1038/icb.2016.117.

Caccamo, A., Branca, C., Piras, I. S., Ferreira, E., Huentelman, M. J., Liang, W. S., Readhead, B., Dudley, J. T., Spangenberg, E. E., Green, K. N., Belfiore, R., Winslow, W., \& Oddo, S. (2017). Necroptosis activation in Alzheimer's disease. Nature neuroscience, 20(9), 1236-1246. doi: 10.1038/nn.4608.

Cahilog, Z., Zhao, H., Wu, L., Alam, A., Eguchi, S., Weng, H., \& Ma, D. (2020). The Role of Neutrophil NETosis in Organ Injury: Novel Inflammatory Cell Death Mechanisms. Inflammation, 43(6), 2021-2032. doi: 10.1007/s10753-020-01294-x.

Chen, K. W., Demarco, B., Heilig, R., Shkarina, K., Boettcher, A., Farady, C. J., Pelczar, P., \& Broz, P. (2019). Extrinsic and intrinsic apoptosis activate pannexin-1 to drive NLRP3 inflammasome assembly. The EMBO journal, 38(10), e101638. doi: 10.15252/embj.2019101638.

Crawford, K., Bonfiglio, J. J., Mikoč, A., Matic, I., \& Ahel, I. (2018). Specificity of reversible ADP-ribosylation and regulation of cellular processes. Critical reviews in biochemistry and molecular biology, 53(1), 64-82. doi: 10.1080/10409238.2017.1394265.

Elliott, M. R., \& Ravichandran, K. S. (2016). The Dynamics of Apoptotic Cell Clearance. Developmental cell, 38(2), 147-160. doi: 10.1016/j.devcel.2016.06.029.

Evavold, C. L., Ruan, J., Tan, Y., Xia, S., Wu, H., \& Kagan, J. C. (2018). The Pore-Forming Protein Gasdermin D Regulates Interleukin-1 Secretion from Living Macrophages. Immunity, 48(1), 35-44. doi: 10.1016/j.immuni.2017.11.013.

Fatokun, A. A., Dawson, V. L., \& Dawson, T. M. (2014). Parthanatos: mitochondrial-linked mechanisms and therapeutic opportunities. British journal of pharmacology, 171(8), 20002016. doi: 10.1111/bph.12416.

Friedmann Angeli, J. P., Krysko, D. V., \& Conrad, M. (2019). Ferroptosis at the crossroads of cancer-acquired drug resistance and immune evasion. Nature reviews. Cancer, 19(7), 405-414. doi: 10.1038/s41568-019-0149-1.

Galluzzi, L., Vitale, I., Warren, S., Adjemian, S., Agostinis, P., Martinez, A. B., Chan, T. A., Coukos, G., Demaria, S., Deutsch, E., Draganov, D., Edelson, R. L., Formenti, S. C., Fucikova, J., Gabriele, L., Gaipl, U. S., Gameiro, S. R., Garg, A. D., Golden, E., Han, J., ... Marincola, F. M. (2020). Consensus guidelines for the definition, detection and interpretation of immunogenic cell death. Journal for immunotherapy of cancer, 8(1), e000337. doi: 10.1136/jitc-2019-000337.

Ganesan, R., Hos, N. J., Gutierrez, S., Fischer, J., Stepek, J. M., Daglidu, E., Krönke, M., \& Robinson, N. (2017). Salmonella Typhimurium disrupts Sirt1/AMPK checkpoint control of mTOR to impair autophagy. PLoS pathogens, 13(2), e1006227. doi: 10.1371/journal.ppat.1006227.

Giampazolias, E., Zunino, B., Dhayade, S., Bock, F., Cloix, C., Cao, K., Roca, A., Lopez, J., Ichim, G., Proïcs, E., Rubio-Patiño, C., Fort, L., Yatim, N., Woodham, E., Orozco, S., Taraborrelli, L., Peltzer, N., Lecis, D., Machesky, L., Walczak, H., ... Tait, S. (2017). Mitochondrial permeabilization engages NF-кBdependent anti-tumour activity under caspase deficiency. Nature cell biology, 19(9), 1116-1129. doi: 10.1038/ncb3596.

Gong, Y. N., Guy, C., Olauson, H., Becker, J. U., Yang, M., Fitzgerald, P., Linkermann, A., \& Green, D. R. (2017). ESCRT-III Acts Downstream of MLKL to Regulate Necroptotic Cell Death and Its Consequences. Cell, 169(2), 286-300. doi: 10.1016/j.cell.2017.03.020.

Grootjans, S., Vanden Berghe, T., \& Vandenabeele, P. (2017). Initiation and execution mechanisms of necroptosis: an overview. Cell death and differentiation, 24(7), 1184-1195. doi: 10.1038/cdd.2017.65.

Han, Q., Ma, Y., Wang, H., Dai, Y., Chen, C., Liu, Y., Jing, L., \& Sun, X. (2018). Resibufogenin suppresses colorectal cancer growth and metastasis through RIP3-mediated necroptosis. Journal of translational medicine, 16(1), 201. doi: 10.1186/s12967-018-1580-x.

Hayashi, A., Yavas, A., McIntyre, C. A., Ho, Y. J., Erakky, A., Wong, W., Varghese, A. M., Melchor, J. P., Overholtzer, M., O'Reilly, E. M., Klimstra, D. S., Basturk, O., \& IacobuzioDonahue, C. A. (2020). Genetic and clinical correlates of entosis in pancreatic ductal adenocarcinoma. Modern pathology : an official journal of the United States and Canadian Academy of Pathology, Inc, 33(9), 1822-1831. doi: 10.1038/s41379-0200549-5.

Hocsak, E., Szabo, V., Kalman, N., Antus, C., Cseh, A., Sumegi, K., Eros, K., Hegedus, Z., Gallyas, F., Jr, Sumegi, B., \& Racz, B. (2017). PARP inhibition protects mitochondria and reduces ROS production via PARP-1-ATF4-MKP-1-MAPK retrograde pathway. Free radical biology \& medicine, 108, 770-784. doi: 10.1016/j.freeradbiomed.2017.04.018.

Huang, X., Xiao, F., Li, Y., Qian, W., Ding, W., \& Ye, X. (2018). Bypassing drug resistance by triggering necroptosis: recent advances in mechanisms and its therapeutic exploitation in leukemia. Journal of experimental \& clinical cancer research: CR, 37(1), 310. doi: 10.1186/s13046-018-0976-z.

Johnson, D. C., Taabazuing, C. Y., Okondo, M. C., Chui, A. J., Rao, S. D., Brown, F. C., Reed, C., Peguero, E., de Stanchina, E., Kentsis, A., \& Bachovchin, D. A. (2018). DPP8/DPP9 inhibitorinduced pyroptosis for treatment of acute myeloid leukemia. $\mathrm{Na}$ ture medicine, 24(8), 1151-1156. doi: 10.1038/s41591-0180082-y.

Jorch, S. K., \& Kubes, P. (2017). An emerging role for neutrophil extracellular traps in noninfectious disease. Nature medicine, 23(3), 279-287. doi: 10.1038/nm.4294.

Jorgensen, I., Rayamajhi, M., \& Miao, E. A. (2017). Programmed cell death as a defence against infection. Nature reviews. Immunology, 17(3), 151-164. doi: 10.1038/nri.2016.147.

Kambara, H., Liu, F., Zhang, X., Liu, P., Bajrami, B., Teng, Y., Zhao, L., Zhou, S., Yu, H., Zhou, W., Silberstein, L. E., Cheng, T., Han, M., Xu, Y., \& Luo, H. R. (2018). Gasdermin D Exerts 
Anti-inflammatory Effects by Promoting Neutrophil Death. Cell reports, 22(11), 2924-2936. doi: 10.1016/j.celrep.2018.02.067.

Kearney, C. J., \& Martin, S. J. (2017). An Inflammatory Perspective on Necroptosis. Molecular cell, 65(6), 965-973. doi: 10.1016/j.molcel.2017.02.024.

Kessel, D. (2019). Apoptosis, Paraptosis and Autophagy: Death and Survival Pathways Associated with Photodynamic Therapy. Photochemistry and photobiology, 95(1), 119-125. doi: 10.1111/php.12952.

Kessel, D. (2020). Photodynamic therapy: apoptosis, paraptosis and beyond. Apoptosis: an international journal on programmed cell death, 25(9-10), 611-615. doi: 10.1007/s10495020-01634-0.

Khan, I., Yousif, A., Chesnokov, M., Hong, L., \& Chefetz, I. (2021). A decade of cell death studies: Breathing new life into necroptosis. Pharmacology \& therapeutics, 220, 107717. doi: 10.1016/j.pharmthera.2020.107717.

Kim, E. H., Shin, D., Lee, J., Jung, A. R., \& Roh, J. L. (2018). CISD2 inhibition overcomes resistance to sulfasalazineinduced ferroptotic cell death in head and neck cancer. Cancer letters, 432, 180-190. doi: 10.1016/j.canlet.2018.06.018.

Kim, E. H., Wong, S. W., \& Martinez, J. (2019). Programmed Necrosis and Disease:We interrupt your regular programming to bring you necroinflammation. Cell death and differentiation, 26(1), 25-40. doi: 10.1038/s41418-018-0179-3.

Kolb, J. P., Oguin III, T. H., Oberst, A., \& Martinez, J. (2017). Programmed cell death and inflammation: winter is coming. Trends in immunology, 38(10), 705-718. doi: 10.1016/j.it.2017.06.009.

Lawlor, K. E., Feltham, R., Yabal, M., Conos, S. A., Chen, K. W., Ziehe, S., ... \& Vince, J. E. (2017). XIAP loss triggers RIPK3and caspase-8-driven IL-1 $\beta$ activation and cell death as a consequence of TLR-MyD88-induced cIAP1-TRAF2 degradation. Cell reports, 20(3), 668-682. doi: 10.1016/j.celrep.2017.06.073.

Levine, B., \& Kroemer, G. (2019). Biological Functions of Autophagy Genes: A Disease Perspective. Cell, 176(1-2), 11-42. doi: 10.1016/j.cell.2018.09.048.

Li, J., Cao, F., Yin, H. L., Huang, Z. J., Lin, Z. T., Mao, N., Sun, B., \& Wang, G. (2020). Ferroptosis: past, present and future. Cell death \& disease, 11(2), 88. doi: 10.1038/s41419-0202298-2.

Linkermann A. (2019). Death and fire-the concept of necroinflammation. Cell death and differentiation, 26(1), 1-3. doi: 10.1038/s41418-018-0218-0.

Liu, L., \& Sun, B. (2019). Neutrophil pyroptosis: new perspectives on sepsis. Cellular and molecular life sciences: CMLS, 76(11), 2031-2042. doi: 10.1007/s00018-019-03060-1.

Liu, W., Chen, B., Wang, Y., Meng, C., Huang, H., Huang, X. R., Qin, J., Mulay, S. R., Anders, H. J., Qiu, A., Yang, B., Freeman, G. J., Lu, H. J., Lin, H. Y., Zheng, Z. H., Lan, H. Y., Huang, Y., \& Xia, Y. (2018). RGMb protects against acute kidney injury by inhibiting tubular cell necroptosis via an MLKL-dependent mechanism. Proceedings of the National Academy of Sciences of the United States of America, 115(7), E1475-E1484. doi: 10.1073/pnas.1716959115.

Lu, H., Zhang, S., Wu, J., Chen, M., Cai, M. C., Fu, Y., Li, W., Wang, J., Zhao, X., Yu, Z., Ma, P., \& Zhuang, G. (2018). Molecular Targeted Therapies Elicit Concurrent Apoptotic and GSDME-Dependent Pyroptotic Tumor Cell Death. Clinical cancer research: an official journal of the American Association for Cancer Research, 24(23), 6066-6077. doi: 10.1158/1078-0432.CCR-18-1478.

Lyamzaev, K. G., Knorre, D. A., \& Chernyak, B. V. (2020). Mitoptosis, Twenty Years After. Biochemistry. Biokhimiia, 85(12), 1484-1498. doi: 10.1134/S0006297920120020.

Martyshuk, T. V., Gutyj, B. V., Zhelavskyi, M. M., Midyk, S. V., Fedorchenko, A. M., Todoriuk, V. B., ... \& Iglitskej, I. I. (2020). Effect of Butaselmevit-Plus on the immune system of piglets during and after weaning. Ukrainian Journal of Ecology, 10(2), 347-352. doi: 10.15421/2020 106.

Mijaljica, D., Prescott, M., \& Devenish, R. J. (2010). Mitophagy and mitoptosis in disease processes. Methods in molecular bi- ology (Clifton, N.J.), 648, 93-106. doi: 10.1007/978-1-60761756-3_6.

Mlynarczuk-Bialy, I., Dziuba, I., Sarnecka, A., Platos, E., Kowalczyk, M., Pels, K. K., Wilczynski, G. M., Wojcik, C., \& Bialy, L. P. (2020). Entosis: From Cell Biology to Clinical Cancer Pathology. Cancers, 12(9), 2481. doi: 10.3390/cancers12092481.

Naderer, T., \& Fulcher, M. C. (2018). Targeting apoptosis pathways in infections. Journal of leukocyte biology, 103(2), 275285. doi: 10.1189/JLB.4MR0717-286R.

Ning, X., Wang, Y., Jing, M., Sha, M., Lv, M., Gao, P., Zhang, R., Huang, X., Feng, J. M., \& Jiang, Z. (2019). Apoptotic Caspases Suppress Type I Interferon Production via the Cleavage of cGAS, MAVS, and IRF3. Molecular cell, 74(1), 19-31. doi: 10.1016/j.molcel.2019.02.013.

Okondo, M. C., Johnson, D. C., Sridharan, R., Go, E. B., Chui, A. J., Wang, M. S., Poplawski, S. E., Wu, W., Liu, Y., Lai, J. H., Sanford, D. G., Arciprete, M. O., Golub, T. R., Bachovchin, W. W., \& Bachovchin, D. A. (2017). DPP8 and DPP9 inhibition induces pro-caspase-1-dependent monocyte and macrophage pyroptosis. Nature chemical biology, 13(1), 46-53. doi: $10.1038 /$ nchembio. 2229 .

Orning, P., Weng, D., Starheim, K., Ratner, D., Best, Z., Lee, B., Brooks, A., Xia, S., Wu, H., Kelliher, M. A., Berger, S. B., Gough, P. J., Bertin, J., Proulx, M. M., Goguen, J. D., Kayagaki, N., Fitzgerald, K. A., \& Lien, E. (2018). Pathogen blockade of TAK1 triggers caspase-8-dependent cleavage of gasdermin D and cell death. Science (New York, N.Y.), 362(6418), 1064-1069. doi: 10.1126/science.aau2818.

Orzalli, M. H., \& Kagan, J. C. (2017). Apoptosis and Necroptosis as Host Defense Strategies to Prevent Viral Infection. Trends in cell biology, 27(11), 800-809. doi: 10.1016/j.tcb.2017.05.007.

Papayannopoulos, V. (2018). Neutrophil extracellular traps in immunity and disease. Nature reviews. Immunology, 18(2), 134-147. doi: 10.1038/nri.2017.105.

Platnich, J. M., Chung, H., Lau, A., Sandall, C. F., BondziSimpson, A., Chen, H. M., Komada, T., Trotman-Grant, A. C., Brandelli, J. R., Chun, J., Beck, P. L., Philpott, D. J., Girardin, S. E., Ho, M., Johnson, R. P., MacDonald, J. A., Armstrong, G. D., \& Muruve, D. A. (2018). Shiga Toxin/Lipopolysaccharide Activates Caspase-4 and Gasdermin D to Trigger Mitochondrial Reactive Oxygen Species Upstream of the NLRP3 Inflammasome. Cell reports, 25(6), 1525-1536. doi: 10.1016/j.celrep.2018.09.071.

Rathkey, J. K., Zhao, J., Liu, Z., Chen, Y., Yang, J., Kondolf, H. C., Benson, B. L., Chirieleison, S. M., Huang, A. Y., Dubyak, G. R., Xiao, T. S., Li, X., \& Abbott, D. W. (2018). Chemical disruption of the pyroptotic pore-forming protein gasdermin D inhibits inflammatory cell death and sepsis. Science immunology, 3(26), eaat2738. doi: 10.1126/sciimmunol.aat2738.

Rijal, D., Ariana, A., Wight, A., Kim, K., Alturki, N. A., Aamir, Z., Ametepe, E. S., Korneluk, R. G., Tiedje, C., Menon, M. B., Gaestel, M., McComb, S., \& Sad, S. (2018). Differentiated macrophages acquire a pro-inflammatory and cell deathresistant phenotype due to increasing XIAP and p38-mediated inhibition of RipK1. The Journal of biological chemistry, 293(30), 11913-11927. doi: 10.1074/jbc.RA118.003614.

Ritter, M., Bresgen, N., \& Kerschbaum, H. H. (2021). From Pinocytosis to Methuosis-Fluid Consumption as a Risk Factor for Cell Death. Frontiers in cell and developmental biology, 9, 651982. doi: $10.3389 /$ fcell.2021.651982.

Robinson, N., Ganesan, R., Hegedús, C., Kovács, K., Kufer, T. A., \& Virág, L. (2019). Programmed necrotic cell death of macrophages: Focus on pyroptosis, necroptosis, and parthanatos. Redox biology, 26, 101239. doi: 10.1016/j.redox.2019.101239.

Rogers, C., Fernandes-Alnemri, T., Mayes, L., Alnemri, D., Cingolani, G., \& Alnemri, E. S. (2017). Cleavage of DFNA5 by caspase-3 during apoptosis mediates progression to secondary necrotic/pyroptotic cell death. Nature communications, 8, 14128. doi: $10.1038 /$ ncomms 14128 .

Ros, U., Peña-Blanco, A., Hänggi, K., Kunzendorf, U., Krautwald, S., Wong, W. W., \& García-Sáez, A. J. (2017). Necroptosis 
Execution Is Mediated by Plasma Membrane Nanopores Independent of Calcium. Cell reports, 19(1), 175-187. doi: 10.1016/j.celrep.2017.03.024.

Rühl, S., Shkarina, K., Demarco, B., Heilig, R., Santos, J. C., \& Broz, P. (2018). ESCRT-dependent membrane repair negatively regulates pyroptosis downstream of GSDMD activation. Science (New York, N.Y.), 362(6417), 956-960. doi: 10.1126/science.aar7607.

Sachet, M., Liang, Y. Y., \& Oehler, R. (2017). The immune response to secondary necrotic cells. Apoptosis: an international journal on programmed cell death, 22(10), 1189-1204. doi: 10.1007/s10495-017-1413-z.

Sarhan, J., Liu, B. C., Muendlein, H. I., Weindel, C. G., Smirnova, I., Tang, A. Y., Ilyukha, V., Sorokin, M., Buzdin, A., Fitzgerald, K. A., \& Poltorak, A. (2019). Constitutive interferon signaling maintains critical threshold of MLKL expression to license necroptosis. Cell death and differentiation, 26(2), 332347. doi: 10.1038/s41418-018-0122-7.

Sborgi, L., Rühl, S., Mulvihill, E., Pipercevic, J., Heilig, R., Stahlberg, H., Farady, C. J., Müller, D. J., Broz, P., \& Hiller, S. (2016). GSDMD membrane pore formation constitutes the mechanism of pyroptotic cell death. The EMBO journal, 35(16), 1766-1778. doi: 10.15252/embj.201694696.

Snyder, A. G., Hubbard, N. W., Messmer, M. N., Kofman, S. B., Hagan, C. E., Orozco, S. L., Chiang, K., Daniels, B. P., Baker, D., \& Oberst, A. (2019). Intratumoral activation of the necroptotic pathway components RIPK1 and RIPK3 potentiates antitumor immunity. Science immunology, 4(36), eaaw2004. doi: 10.1126/sciimmunol.aaw2004.

Speir, M., Lawlor, K. E., Glaser, S. P., Abraham, G., Chow, S., Vogrin, A., Schulze, K. E., Schuelein, R., O'Reilly, L. A., Mason, K., Hartland, E. L., Lithgow, T., Strasser, A., Lessene, G., Huang, D. C., Vince, J. E., \& Naderer, T. (2016). Eliminating Legionella by inhibiting BCL-XL to induce macrophage apoptosis. Nature microbiology, 1, 15034. doi: 10.1038/nmicrobiol.2015.34.

Swerdlow, N. S., \& Wilkins, H. M. (2020). Mitophagy and the Brain. International journal of molecular sciences, 21(24), 9661. doi: 10.3390/ijms21249661.

Szwed, M., Sønstevold, T., Øverbye, A., Engedal, N., Grallert, B., Mørch, Ý., Sulheim, E., Iversen, T. G., Skotland, T., Sandvig, K., \& Torgersen, M. L. (2019). Small variations in nanoparticle structure dictate differential cellular stress responses and mode of cell death. Nanotoxicology, 13(6), 761-782. doi: 10.1080/17435390.2019.1576238.

Tang, R., Xu, J., Zhang, B., Liu, J., Liang, C., Hua, J., Meng, Q., Yu, X., \& Shi, S. (2020). Ferroptosis, necroptosis, and pyroptosis in anticancer immunity. Journal of hematology \& oncology, 13(1), 110. doi: 10.1186/s13045-020-00946-7.

Tonnus, W., \& Linkermann, A. (2017). The in vivo evidence for regulated necrosis. Immunological reviews, 277(1), 128-149. doi: 10.1111/imr.12551.

Wang, Y. Y., Liu, X. L., \& Zhao, R. (2019). Induction of Pyroptosis and Its Implications in Cancer Management. Frontiers in oncology, 9, 971. doi: 10.3389/fonc.2019.00971.

Wang, Y., Gao, W., Shi, X., Ding, J., Liu, W., He, H., Wang, K., \& Shao, F. (2017). Chemotherapy drugs induce pyroptosis through caspase- 3 cleavage of a gasdermin. Nature, 547(7661), 99-103. doi: 10.1038/nature22393.

Wang, Y., Shi, P., Chen, Q., Huang, Z., Zou, D., Zhang, J., Gao, X., \& Lin, Z. (2019). Mitochondrial ROS promote macrophage pyroptosis by inducing GSDMD oxidation. Journal of molecular cell biology, 11(12), 1069-1082. doi: 10.1093/jmcb/mjz020.

Wei, Q., Zhu, R., Zhu, J., Zhao, R., \& Li, M. (2019). E2-Induced Activation of the NLRP3 Inflammasome Triggers Pyroptosis and Inhibits Autophagy in HCC Cells. Oncology research, 27(7), 827-834. doi: 10.3727/096504018X15462920753012.

Weinlich, R., Oberst, A., Beere, H. M., \& Green, D. R. (2017). Necroptosis in development, inflammation and disease. Nature reviews. Molecular cell biology, 18(2), 127-136. doi: 10.1038/nrm.2016.149.
Wu, D., Wang, S., Yu, G., \& Chen, X. (2021). Cell Death Mediated by the Pyroptosis Pathway with the Aid of Nanotechnology: Prospects for Cancer Therapy. Angewandte Chemie (International ed. in English), 60(15), 8018-8034. doi: 10.1002/anie.202010281.

Xi, G., Gao, J., Wan, B., Zhan, P., Xu, W., Lv, T., \& Song, Y. (2019). GSDMD is required for effector $\mathrm{CD} 8^{+} \mathrm{T}$ cell responses to lung cancer cells. International immunopharmacology, 74, 105713. doi: 10.1016/j.intimp.2019.105713.

Yablonskyi, V. A., \& Zhelavskyi, M. M. (2014). Stan apoptozu imunokompetentnykh klityn sekretu molochnoi zalozy koriv u rizni periody laktatsii. Naukovo-tekhnichnyi biuleten Naukovodoslidnoho tsentru biobezpeky ta ekolohichnoho kontroliu resursiv APK Dnipropetrovskoho derzhavnoho ahrarnoekonomichnoho universytetu, 2(3), 39-45. URL: http://nbuv.gov.ua/UJRN/ ndbnnde_2014_2_3_8 (in Ukrainian).

Yablonskyi, V. A., \& Zhelavskyi, M. M. (2008). Apoptoz imunokompetentnyh klityn krovi koriv u period laktacii. Naukovyi visnyk Nacional'nogo agrarnogo universitetu, 126, $233-$ 236 (in Ukrainian).

Yablonskyi, V. A., \& Zhelavskyi, M. M. (2010). Osoblyvosti projavu klitynnogo imunnogo zahystu organizmu koriv v rizni periody laktacii. Naukovi dopovidi Nacional'nogo universitetu bioresursiv i pryrodokorystuvannja Ukraini, 2(20), 1-8. URL: http://nd.nubip.edu.ua/2010-4/10yvalsm.pdf (in Ukrainian).

Yang, L., Song, L., Zhao, S., Ma, C., Wu, D., \& Wu, Y. L. (2019). Isobavachalcone reveals novel characteristics of methuosis-like cell death in leukemia cells. Chemico-biological interactions, 304, 131-138. doi: 10.1016/j.cbi.2019.03.011.

Yoon, S., Kovalenko, A., Bogdanov, K., \& Wallach, D. (2017). MLKL, the Protein that Mediates Necroptosis, Also Regulates Endosomal Trafficking and Extracellular Vesicle Generation. Immunity, 47(1), 51-65. doi: 10.1016/j.immuni.2017.06.001.

Yu, S. X., Chen, W., Liu, Z. Z., Zhou, F. H., Yan, S. Q., Hu, G. Q., Qin, X. X., Zhang, J., Ma, K., Du, C. T., Gu, J. M., Deng, X. M., Han, W. Y., \& Yang, Y. J. (2018). Non-Hematopoietic MLKL Protects Against Salmonella Mucosal Infection by Enhancing Inflammasome Activation. Frontiers in immunology, 9, 119. doi: 10.3389/fimmu.2018.00119.

Zargarian, S., Shlomovitz, I., Erlich, Z., Hourizadeh, A., Ofir-Birin, Y., Croker, B. A., Regev-Rudzki, N., Edry-Botzer, L., \& Gerlic, M. (2017). Phosphatidylserine externalization, "necroptotic bodies" release, and phagocytosis during necroptosis. PLoS biology, 15(6), e2002711. doi: 10.1371/journal.pbio.2002711.

Zhang, C. C., Li, C. G., Wang, Y. F., Xu, L. H., He, X. H., Zeng, Q. Z., Zeng, C. Y., Mai, F. Y., Hu, B., \& Ouyang, D. Y. (2019). Chemotherapeutic paclitaxel and cisplatin differentially induce pyroptosis in A549 lung cancer cells via caspase3/GSDME activation. Apoptosis: an international journal on programmed cell death, 24(3-4), 312-325. doi: 10.1007/s10495-019-01515-1.

Zhelavskyi, M. M. (2004). Nespecyfichna reaktyvnist' organizmu koriv pry mastyti. Naukovyi visnyk LNAVM im. S. Z. Gzhic'kogo, 6(1), 31-35 (in Ukrainian).

Zhelavskyi, M. M. (2005). Biometrichnij analiz pokaznykiv nespecyfichnogo imunnogo zahystu koriv $\mathrm{v}$ rizni periody funkcional'nogo stanu molochnoi zalozy. Naukovo-tehnichnyi bjuleten' instytutu biologii tvaryn i Derzhavnogo naukovodoslidnogo kontrol'nogo instytutu veterynarnyh preparativ ta kormovyh dobavok, 6(2), 70-73 (in Ukrainian).

Zhelavskyi, M. M. (2006). Doslidzhennja metabolichnoi aktyvnosti nejtrofiliv molozyva koriv v NST-testi. Naukovyi visnyk LNAVM im. S. Z. Gzhyc'kogo, 8(3(30), 40-42 (in Ukrainian).

Zhelavskyi, M. M. (2007). Apoptoz nejtrofil'nyh granulocytiv krovi koriv pry fiziologichnij laktacii. Visnyk SNAU, 8(19), 3739 (in Ukrainian).

Zhelavskyi, M. M. (2008). Funkcional'na aktyvnist' ta stan apoptozu fagocytiv krovi koriv v period laktacii. Naukovyi visnyk Scientific Messenger of LNAVM im. S. Z. Gzhic'kogo, 10(2(37), 72-75 (in Ukrainian). 
Zhelavskyi, M. M. (2009). Funkcional'nyi stan ta apoptoz fagocytiv sekretu molochnoi zalozy koriv pry subklinichnomu mastyti. Visnyk BDAU, 60(1), 57-60 (in Ukrainian).

Zhelavskyi, M. M. (2010). Zminy fagocytarnogo zahystu organizmu koriv pry subklinichnomu mastyti. Naukovyi visnyk Scientific Messenger of LNUVMB im. S. Z. Gzhyckogo, 12(2(44), 93-96 (in Ukrainian).

Zhelavskyi, M. M. (2011). Zminy protymikrobnogo potencialu fagocytiv za mastytu koriv. Problemy zooinzhenerii ta veterinarnoi medycyny, 23(2), 438-440 (in Ukrainian).

Zhelavskyi, M. M. (2017). Ontogenetic features of the formation of local immune protection of the mammary gland of cows (literature review and original research). Scientific Messenger of LNUVMB named after S.Z. Gzhytskyj, 19(79), 3-8. doi: $10.15421 /$ nvlvet7801.

Zhelavskyi, M. M. (2019). Study of innate factors in the local immune defense of the genital organs of dogs and cats. Scientific Messenger of LNUVMB named after S.Z. Gzhytskyj, 21(93), 98-102. doi: 10.32718/nvlvet9317.

Zhelavskyi, M. M. (2021). The role of neutrophil on subclinical mastitis in cows. Polish Journal of Natural Sciences, 36(1), 107-115. URL: http://www.uwm.edu.pl/polish-journal/sites/ default/files/issues/articles/07-zhelavskyi.pdf.

Zhelavskyi, M. M., \& Shunin, I. M. (2017). The status of extracellular antimicrobial potential of phagocytes genitals of cats. Scientific Messenger of Lviv National University of LNUVMB named after S.Z. Gzhytskyj, 19(73), 71-74. doi: 10.15421/nvlvet7315.

Zhelavskyi, M., Shunin, I., \& Midyk, S. (2020). Extracellular antibacterial defense mechanisms of neutrophil granulocytes and their role in pathogenesis of pyometra (cases) in cats. Polish Journal of Natural Sciences, 35(3), 363-378. URL: http://www.uwm.edu.pl/ polish-journal/sites/default/files/issues/articles/09-zhelavsky.pdf.
Zhelavskyi, M., Kernychnyi, S., Mizyk, V., Dmytriv, O., \& Betlinska, T. (2020). The importance of metabolic processes and immune responses in the development of pathology of cows during pregnancy and postpartum periods. Ukrainian Journal of Veterinary and Agricultural Sciences, 3(2), 36-41. doi: 10.32718/ujvas3-2.06.

Zhelavskyi, N. N. (2015). Funkcional'noe sostojanie kletochnyh faktorov lokal'nogo immuniteta molochnoj zhelezy korov v razlichnye periody laktacii. Aktual'nye problemy intensivnogo razvitija zhivotnovodstva, 18(2), 187-197 (in Russian).

Zhelavskyi, N. N. (2017). Izmenenie lokal'noj immunnoj zashhity molochnoj zhelezy korov pri mastite. Uchenye zapiski uchrezhdenija obrazovanija "Vitebskaja ordena "Znak pocheta" "Znak Pocheta" GAVM", 53(2), 53-56. URL: http://repo.vsavm.by/handle/123456789/2023 (in Russian).

Zhelavskyi, N. N., \& Yablonskyi, V. A. (2009). Izmenenie funkcional'nogo sostojanija kletochnogo zvena immunobiologicheskoj zashhity organizma korov pri subklinicheskom mastite. Uchenye zapiski: Nauchno-prakticheskij zhurnal uchrezhdenija obrazovanija "Vitebskaja ordena «Znak Pocheta" GAVM", 45(1), 244-246 (in Russian).

Zhou, B., Liu, J., Kang, R., Klionsky, D. J., Kroemer, G., \& Tang, D. (2020). Ferroptosis is a type of autophagy-dependent cell death. Seminars in cancer biology, 66, 89-100. doi: 10.1016/j.semcancer.2019.03.002.

Zhou, B., Zhang, J. Y., Liu, X. S., Chen, H. Z., Ai, Y. L., Cheng, K., Sun, R. Y., Zhou, D., Han, J., \& Wu, Q. (2018). Tom20 senses iron-activated ROS signaling to promote melanoma cell pyroptosis. Cell research, 28(12), 1171-1185. doi: 10.1038/s41422-018-0090-y. 